\title{
Application of short stem endoprosthesis in total hip arthroplasty in patients with haemophilia - preliminary report
}

\section{Zastosowanie endoprotezy krótkotrzpieniowej w endoprotezoplastyce całkowitej stawów biodrowych u pacjentów z hemofilia - doniesienie wstępne}

\author{
Andrzej Kotela \\ Department of Orthopaedics and Traumatology of Musculoskeletal System, $1^{\text {st }}$ Faculty of Medicine, Medical University of Warsaw, \\ Warsaw, Poland \\ Head of the Department: Prof. Paweł Małdyk MD, PhD
}

Medical Studies/Studia Medyczne 2016; 32 (4): 263-268

DOI: $10.5114 / \mathrm{ms} .2016 .62314$

Key words: hip arthroplasty, short stem prosthesis, haemophilia, haemophiliac arthropathy.

Słowa kluczowe: endoprotezoplastyka stawu biodrowego, proteza krótkotrzpieniowa, hemofilia, artropatia hemofilowa.

\begin{abstract}
Introduction: Haemophilic arthropathy is one of the most important problems in patients with haemophilia. As a consequence of multiple bleedings into the musculoskeletal system, there occur degenerative changes which lead to serious impairment of the motor system functions, and often to disability even at a young age. In the case of advanced degenerative changes of the hip joint, the treatment of choice is total hip arthroplasty (THA). One attempt of modernization of THA is the concept of metaphyseal fixation. No reports have been published to date concerning the application of a short stem endoprosthesis in total hip arthroplasty in this population.

Aim of the research: To evaluate the preliminary clinical outcomes of THA using short stem endoprostheses in patients with haemophilia.

Material and methods: Between January 2010 and August 2016, 38 THA procedures were performed in patients with inherited bleeding disorders. In 12 cases cementless short stem endoprostheses were applied. Nine patients had been diagnosed with severe haemophilia A and 3 patients with a severe form of haemophilia B. The mean duration of observation was 34.3 months. The post-operative outcomes were evaluated using the HHS scale, WOMAC scale, and VAS scale to assess patient satisfaction with the surgery. Postoperative complications were recorded and analysed, and radiological examination was performed.

Results and conclusions: The preliminary results of THA using short stem endoprostheses are satisfactory and suggest that these implants are a reasonable and appropriate solution for patients with hip arthropathy induced by inherited bleeding disorders. Long-term follow-up is warranted.
\end{abstract}

\section{Streszczenie}

Wprowadzenie: Artropatia hemofilowa jest jednym z najistotniejszych problemów klinicznych u pacjentów z hemofilią. Nawracające krwawienia do układu mięśniowo-szkieletowego prowadzą do uszkodzeń i deformacji stawów, które są przyczyną przewlekłych dolegliwości bólowych, ograniczenia ruchomości, a w konsekwencji kalectwa, często już u osób w młodym wieku. W przypadku bardzo dużego zniszczenia stawu biodrowego endoprotezoplastyka całkowita stanowi jedyną metodę, która może zapewnić poprawę jakości życia i zniesienie bólu. Jedną z prób unowocześnienia aloplastyki stawu biodrowego stanowi wprowadzenie bezcementowych endoprotez krótkotrzpieniowych. Dotąd nie przeprowadzono żadnych badań oceniających wyniki zastosowania tych protez u pacjentów z hemofilią.

Cel pracy: Ocena wstępnych wyników klinicznych endoprotezoplastyki całkowitej stawów biodrowych z zastosowaniem protez krótkotrzpieniowych u pacjentów z hemofilią.

Materiał i metody: Od stycznia 2010 do sierpnia 2016 r. wykonano 36 endoprotezoplastyk całkowitych stawów biodrowych u pacjentów z hemofilią. W 12 przypadkach zastosowano endoprotezy krótkotrzpieniowe. Dziewięciu operowanych chorowało na ciężką hemofilię A, w 3 przypadkach stwierdzono ciężką postać hemofilii B. Czas obserwacji wynosił średnio 34,3 miesiąca. Do oceny wyników klinicznych leczenia wykorzystano skale HHS, WOMAC oraz VAS oceniającą zadowolenie z przeprowadzonej operacji. W pracy dokonano również analizy powikłań oraz oceny radiogramów pooperacyjnych.

Wyniki i wnioski: Wyniki wstępne są satysfakcjonujące i potwierdzają zasadność stosowania endoprotez krótkotrzpieniowych $\mathrm{w}$ aloplastyce stawów biodrowych u pacjentów z hemofilią. W celu potwierdzenia uzyskanych wyników należy przeprowadzić kolejne badania oceniające efekty odległe. 


\section{Introduction}

Haemophilia is a rare inherited disorder in which blood clotting is impaired, its incidence being approximately 1 : $16000[1,2]$. Two basic types of this hemorrhagic diathesis are distinguished: haemophilia A, caused by the genetic deficiency of clotting factor VIII, and haemophilia B, which is due to deficiency of clotting factor IX [1-3].

Haemophilic arthropathy is one of the most important problems in patients with haemophilia. The initial bleedings into the joints occur in the first years of life; they most frequently concern the knee, elbow and ankle joints, and considerably more rarely the hip joints. As a consequence of multiple bleedings into the musculoskeletal system, there occur degenerative changes which lead to serious impairment of the motor system functions, and often to disability even at a young age [4].

In the case of advanced degenerative changes of the hip joint, the treatment of choice is total hip arthroplasty (THA). The essence of this procedure is the replacement of pathologically damaged joint surfaces with permanently and stably embedded elements of the artificial joint. This method is applied in patients in whom all the less invasive treatment options have been exhausted. The success of surgery depends on the correct embedding of the implant, creating conditions similar to those which prevail in a healthy, physiologically structured joint.

The number of various types of endoprostheses of the hip joint available on the market is constantly increasing, and new sets of instruments which continue to emerge facilitate their proper implantation. For almost 20 years, in the improvement of the construction of prostheses, there has been a tendency towards the introduction of techniques which maximally save the bone tissue. In young and middle-aged patients, the solution for saving bone tissue is so-called short stem endoprostheses. These are characterized by a different construction of the cementless stem, which is considerably shorter and physiologically burdens the proximal end of the femoral bone, and is a saving surgical technique which requires smaller resection of the femoral neck (Figure 1) [5, 6].

It should be emphasized that in the group of patients with haemophilia, hip joint surgery is a very rarely performed and demanding procedure. At present, it is still considered that the risk of post-opera-
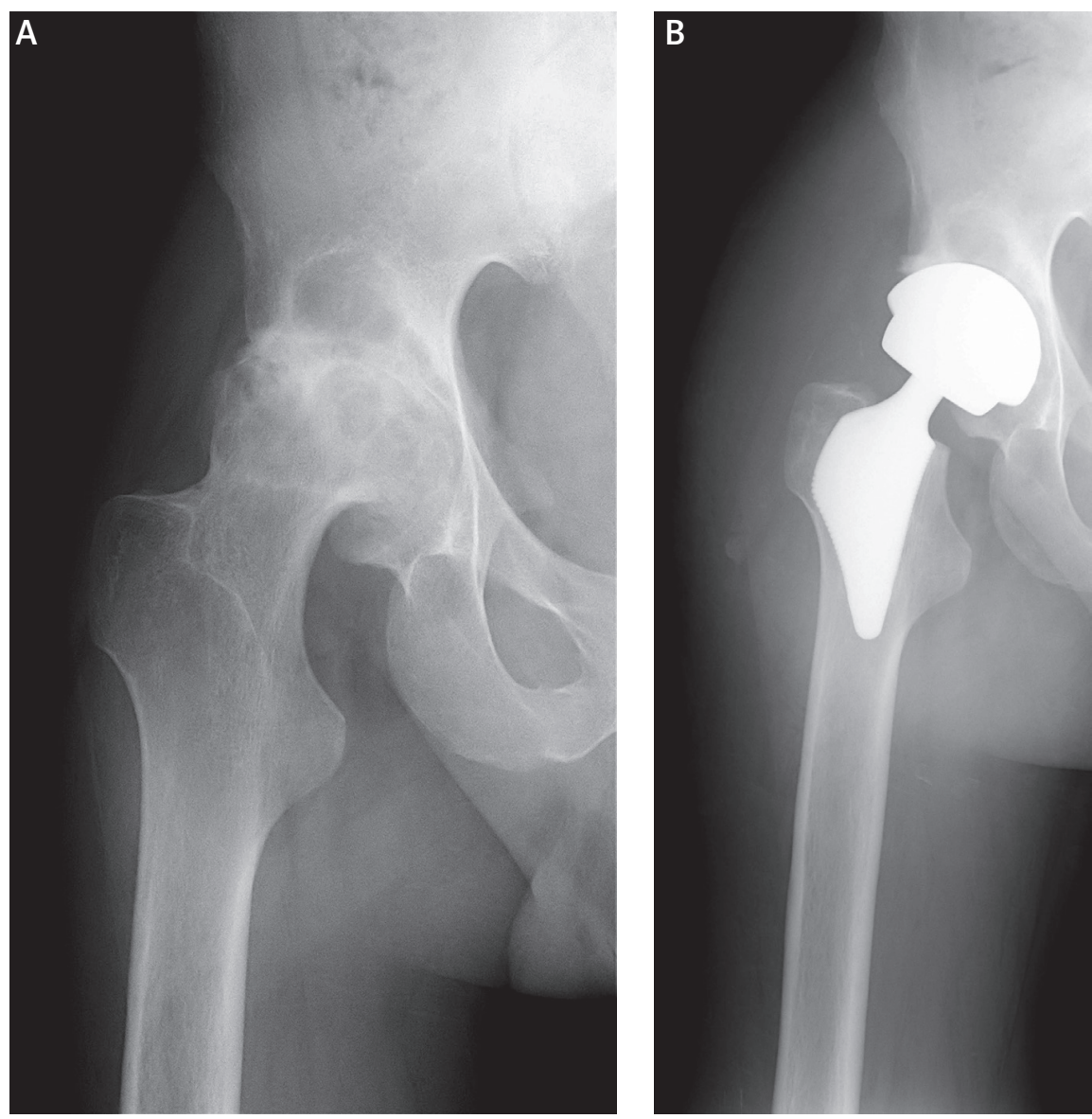

Figure 1. Short-stem total hip arthroplasty on a patient with haemophilia. Preoperative (A) and postoperative (B) views 
tive complications in the group of patients with haemophilia is higher compared with the population of patients without blood clotting disorders. Also, the number of scientific publications summing up the outcomes of hip replacement using modern implants is extremely limited [7]. In association with the increasingly common use of short stems in hip replacement, and the fact of widening the scope of indications for their use together with the acquisition of experience, the researchers decided to evaluate the legitimacy of the application of the stems discussed in THA in patients with haemophilia. To the best of our knowledge, in the relevant literature, no reports have been published to date concerning the evaluation of the outcomes of hip replacement using short stem endoprostheses in this population.

\section{Aim of the research}

The objective of the study was to evaluate the preliminary clinical outcomes of THA using short stem endoprostheses in patients with congenital blood clotting disorders.

\section{Material and methods}

During the period between January 2010 and August 2016, in the Clinical Department of Orthopaedics and Traumatology at the Central Clinical Hospital of the Ministry of the Interior and Administration in Warsaw, 38 procedures of THA were performed in patients with inherited bleeding disorders. In 26 cases, implantations of long stem endoprostheses were performed (including 2 cemented), whereas in 12 cases cementless short stem endoprostheses were applied, which are the subject of the present study.

The selected group of 12 patients with implanted short stem endoprostheses comprised men aged at the time of surgery from 25 to 57, mean age 42.98. Nine patients had been diagnosed with severe haemophilia A and 3 patients with a severe form of haemophilia B. Two patients in the study population had circulating clotting factor inhibitor; 6 patients were seropositive for hepatitis $\mathrm{C}$ virus (HCV), whereas none of the patients were seropositive for human immunodeficiency virus (HIV) or hepatitis B virus (HBV). In 5 cases, the surgery was performed on the right hip joint, in 7 cases on the left joint. The mean height in this population was $1.76 \pm 0.07 \mathrm{~m}(1.66-1.91 \mathrm{~m})$, mean weight $74.33 \pm 9.96 \mathrm{~kg}$ (range: $51-90 \mathrm{~kg}$ ). The mean body mass index (BMI) was $23.97 \mathrm{~kg} / \mathrm{m}^{2}$ (range: $18.68-29.03 \mathrm{~kg}$ / $\mathrm{m}^{2}$ ), with 3 overweight patients (BMI: $25-29.9 \mathrm{~kg} / \mathrm{m}^{2}$ ) and none who were underweight $\left(\mathrm{BMI}<18.5 \mathrm{~kg} / \mathrm{m}^{2}\right)$.

In the material examined, short stem endoprostheses from various producers were implanted: in 8 cases the stem PROXIMA (DePuy Synthes), in 2 cases Minima (Lima), in 1 case TRI-LOCK (DePuy Synthes), and in 1 patient Furlong Evolution (JRI Orthopaedics Ltd.) The following acetabular cups were applied:
Pinnacle (DePuy Synthes) in 5 cases, DeltaMotion (DePuy Synthes) in 4 cases, Delta-PF (Lima) in 2 cases, and Trinity (Corin) in 1 patient. The articulation type of ceramic-on-ceramic was applied in 4 cases, while in the remaining patients ceramic-on-polyethylene articulation was applied.

The study was approved by the Ethical Review Board, and informed consent was obtained from all of the study participants. Participation in the study was voluntary, and anonymity was ensured in accordance with the Act on the Protection of Personal Data of 29 August 1997 (Journal of Laws, No. 133, Item 883). The duration of observation of patients was 3-66 months (mean: 34.36 months).

The patients were prepared for the surgical procedure (in the aspect of haematology) in the Clinic of Homeostatic Disorders at the Institute of Haematology and Transfusion Medicine (IHIT) in Warsaw. On the day of surgery they were transported to the Clinical Department of Orthopaedics and Traumatology at the Central Clinical Hospital of the Ministry of the Interior and Administration in Warsaw, where the surgery was performed. In all patients the WatsonJones anterolateral approach was applied by the same surgeon experienced in endoprosthesoplasty of hip joints. After the surgery, the patients were returned to the Clinic of Homeostatic Disorders (IHIT), where post-operative treatment was continued. The drains were usually removed on days 2-3 after the surgery, depending on the amount of drainage. All the patients who had undergone the surgery were covered by an appropriate physiotherapeutic programme, which was first performed in the Clinic of Homeostatic Disorders IHIT, and later in ambulatory conditions. The patients were positioned in an upright position on the first day after the surgery. According to the general state of health, the patients were gradually taught to walk, putting full weight on the operated leg, first using a Zimmer frame, subsequently with elbow crutches.

The patients stayed in hospital for 14-21 days. Prior to discharge from the hospital, the patients who had undergone surgery were given an appointment date for the first check-up examination after 6 weeks. The subsequent check-ups took place after 3, 6, 12 months, and subsequently, once a year.

Between May and July 2016, all patients qualified for the study were subjected to additional medical control, for clinical and overall assessment. All of them completed questionnaires. The post-operative outcomes were evaluated using the Harris Hip Score (HHS) [8], the 5-point Likert version of Western Ontario and McMaster Osteoarthritis Index (WOMAC) scale [9], and the visual analogue scale (VAS) to assess patient satisfaction with the surgery [10]. In addition, patients were asked to provide a 'Yes' or 'No' response to the question: 'Would you be willing to have the 
Table 1. Results obtained according to individual scales

\begin{tabular}{|lccc|}
\hline Scale/sub-scale & Mean \pm SD & Min.-Max. \\
\cline { 2 - 4 } & PHS & $39.83 \pm 7.45$ & $20-44$ \\
\cline { 2 - 4 } & $\begin{array}{c}\text { Function } \\
\text { Range } \\
\text { of motion }\end{array}$ & $35.41 \pm 4.56$ & $29-42$ \\
\cline { 2 - 4 } & $\begin{array}{c}\text { Absence } \\
\text { of deformity }\end{array}$ & $4 \pm 0.36$ & $4.25-5$ \\
\cline { 2 - 4 } WOMAC & $\begin{array}{c}\text { Total } \\
\text { Pain }\end{array}$ & $1.83 \pm 2.58 \pm 11.03$ & $58.25-94.25$ \\
\cline { 2 - 4 } & \begin{tabular}{c} 
Stiffness \\
\cline { 2 - 4 }
\end{tabular} & $1 \pm 1.34$ & $0-9$ \\
\hline $\begin{array}{c}\text { Physical } \\
\text { function }\end{array}$ & $15.05 \pm 13.93$ & $0-46$ \\
\cline { 2 - 4 } VAS - satisfaction & $93.41 \pm 6.58$ & $84-100$ \\
\hline
\end{tabular}

SD - standard deviation, Min. - minimum, Max. - maximum.

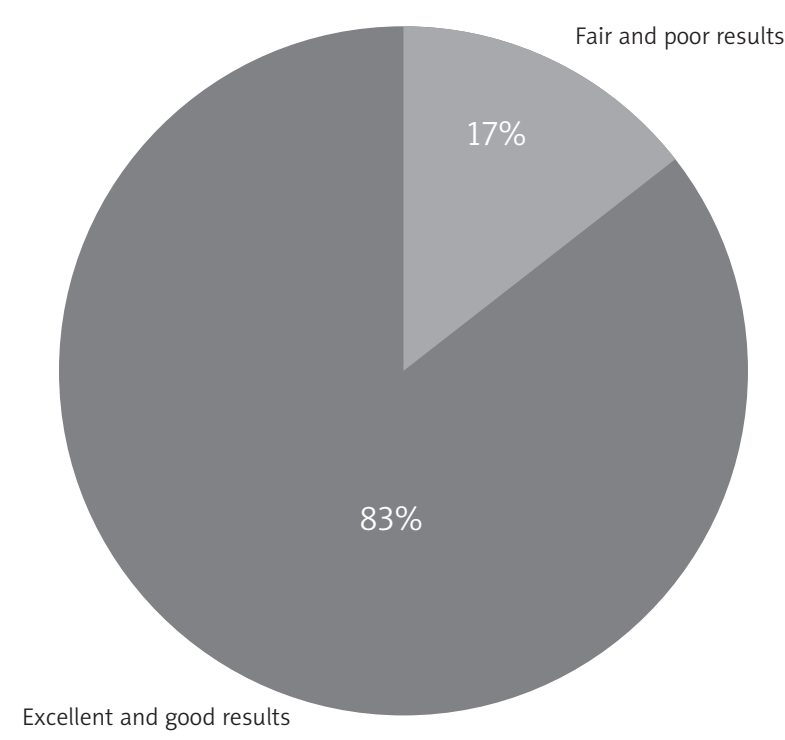

Figure 2. Clinical results according to the HHS score

Table 2. Clinical results according to the HHS score

\begin{tabular}{|lcc|}
\hline Result & No. of patients & Percentage (\%) \\
Excellent & 5 & 41.66 \\
Good & 5 & 41.66 \\
Fair & 1 & 8.33 \\
Poor & 1 & 8.33 \\
\hline
\end{tabular}

same operation again in the future?' Postoperative complications were recorded and analysed, and radiological examination was performed, including assessment of implant setting and possible evidence of loosening, based on anteroposterior and lateral hip joint images.

The HHS applied in the study consists of sub-scales assessing pain (maximum 44), function (maximum 33), activity (maximum 14), deformity (maximum 4), and range of motion (maximum 5) in the examined joint. Thus, the HHS score gives a maximum of 100 points, and the results obtained are equivalent to the results: excellent (90-100 points), good (80-90 points), fair (70-80 points), and poor ( $<70$ points) [8]. Hip range of motion was measured with a goniometer.

The WOMAC scale is composed of 24 items divided into 3 subscales: pain ( 5 items), stiffness ( 2 items), and physical function (17 items). The Likert scale version uses the following descriptors for the items: none, mild, moderate, severe, and extreme. These descriptors correspond to an ordinal scale of 0-4; the scores are summed for items in each subscale with possible ranges as follows: pain $=0-20$, stiffness $=0-8$, and physical function $=0-68[9]$.

\section{Statistical analysis}

Statistical calculations were performed by means of the software package Statistica 6.0 PL, StatSoft, USA. The database was compiled using Microsoft Office Excel.

\section{Results}

Table 1 presents the results obtained by patients according to individual scales. The mean result obtained by patients according to the HHS score was $83.98 \pm 11.03$ points. The results 'very good' and 'good' were obtained jointly in $83 \%$ of patients, while 'fair' and 'poor' were obtained in 17\% (Figure 2, Table 2). According to the WOMAC scale, the patients obtained $17.91 \pm 15.95$ points on average, whereas in the VAS scale assessing satisfaction with the treatment applied the patients obtained $93.41 \pm 6.58$ points. All patients responded 'Yes' when asked if they would undergo the same operations again. Radiological examination revealed correct position of the endoprosthesis components without any signs of loosening or stem migration in all analyzed cases. In one case, intraoperative fracture of the proximal femur occurred and was stabilized with a cerclage wire. No other intra- and postoperative complications were recorded.

\section{Discussion}

Total arthroplasty is a recognized and commonly applied method for the treatment of advanced degenerative changes of the hip joints. In the majority of cases, it allows the relief of pain and a considerable 
improvement in the quality of life of the patients. Good outcomes of these surgical procedures contribute to the increasing popularity of this method, and the number of THA procedures is continuously increasing worldwide.

1950 is considered the key year in the development of endoprosthesoplasty of joints, when McKee introduced a total double prosthesis of the hip joint. It consisted of a metal cup and metal stem head, all fixed by means of acrylic cement. However, the problem with imperfections in metal articulation at that time too often led to the development of metallosis of adjacent tissues. This problem was solved temporarily in 1965 by Sir John Charnley, who replaced the metal cup with a polyethylene equivalent, maintaining the cement stabilization. In this way, in the 1960s, there developed the modern age of endoprosthesoplasty of joints, and Sir Charnley has become the icon of orthopaedic surgery. Since that time, although the sole concept by Charnley has remained unchanged, the types of material used for the construction of the elements of endoprostheses have been constantly changing, as well as their shape and methods of stabilization [11-13].

Many clinical observations have encouraged scientists to discover new methods of fixing prostheses in bones, because over the years the cement was subject to granulation and decomposition - causing aseptic loosening of the endoprostheses. In 1969, Mittelmeier introduced the cementless prosthesis with a threaded cup which enables its anchoring to the bone. Subsequently, there came the age of 'press-fit' stabilization, which was accompanied by parallel research concerning improvement of the articulation surfaces of implant elements, and surfaces remaining in direct contact with the bone $[11,13,14]$.

Generally, for almost 20 years, a tendency has been observed in the improvement of the construction of endoprostheses towards the implementation of techniques which maximally save the bone tissue. In addition, at present, increasingly younger patients who have great expectations with respect to the surgery are qualified for the THA procedures. One attempt of modernization of endoprosthesoplasty of the hip joint is the concept of metaphyseal fixation. This concept was first introduced by Morrey in 1983 $[11,12]$, and assumed that the new design of a tripletapered device will allow achievement of immediate mechanical fixation of the prosthesis within the metaphyseal bone [11]. The advantages of short stems are primarily: physiological distribution of forces exerting an effect on the proximal end of the femoral bone, surgical technique saving the bone tissue and soft tissues, and a more reliable revision procedure in the case of device failure (because of preservation of diaphyseal bone) [11]. Such a design is also in line with the concept of minimally invasive surgery, as it is not necessary to prepare the femoral canal. At present, this design philosophy is increasingly being accepted and will continue to be developed. In association with good outcomes of the use of these endoprostheses, together with the acquisition of experience, the scope of indications for their use is being gradually expanded. In the present study, the researchers, for the first time in the literature, decided to evaluate the outcomes of the application of this type of implant in THA in patients with haemophilia.

From the aspect of a patient, the crucial goal of THA is the relief of pain and restoration of the normal function of the hip joint to a degree which allows free performance of daily activities and tasks without any assistance from others. An effective assessment of the therapeutic process should consider the opinion of the patient and investigate the parameters most important for this patient, which to a large extent determined the selection of research methods applied in this study. In the examined material, which included 12 haemophiliac patients operated on using a short stem, according to the HHS score the majority of the obtained results were 'very good' and 'good' (83\%), and satisfaction with the surgery performed was very high according to the VAS scale (93.4 points). All patients who had undergone surgery stated that they would undergo this procedure again. It should be strongly emphasized that the results obtained in all scales of clinical assessment (HHS, WOMAC) are similar to those reported by other researchers in their reports concerning the evaluation of the outcomes of THA in patients operated on due to degenerative disease of the hip joints. Moreover, in the population examined, no post-operative complications were observed and, in all cases, the radiological assessment showed proper osseointegration. However, the limitations of this study should also be mentioned, including primarily its retrospective character, lack of a control group, and considerable differences with respect to the duration of observation in the study group.

It is noteworthy that in this study preliminary observations were analyzed, and the authors are aware that the numbers in the study group are insufficient to formulate unequivocal conclusions; nevertheless, they are sufficient for the formulation of hypotheses which may be further investigated. Considering the still limited experience using short stem endoprostheses, despite satisfactory results, we advise caution in the increasingly common use of these prostheses and expansion of the indications for their use. One should be aware that the real and fully reliable outcomes of surgery using short stem endoprostheses will only be known after more than a dozen years of their use. In our opinion, the results obtained in the present study require confirmation by further, prospective research on a larger group of patients. 


\section{Conclusions}

The preliminary results of hip joint replacement using short stem endoprostheses are satisfactory and suggest that these implants are a reasonable and appropriate solution for patients with hip arthropathy induced by inherited bleeding disorders. Because of progress with implants, operative technique, as well as haemophilia management therapies, long-term results are promising. Long-term follow-up is warranted.

\section{Conflict of interest}

The authors declare no conflict of interest.

\section{References}

1. Peyvandi F, Garagiola I, Young G. The past and future of haemophilia: diagnosis, treatments, and its complications. Lancet 2016; 388: 187-97.

2. Bolton-Maggs PH, Pasi KJ. Haemophilias A and B. Lancet 2003; 361: 1801-9.

3. Ambroziak P, Żbikowski P, Kotela A, Windyga J, Kotela I. Early complication after total knee arthroplasty in a haemophilia A patient. Studia Medyczne 2014; 30: 39-42.

4. Rodriguez-Merchan EC. Aspects of current management: orthopaedic surgery in haemophilia. Haemophilia 2012; 18: 8-16.

5. Ghera S, Pavan L. The DePuy Proxima hip: a short stem for total hip arthroplasty. Early experience and technical considerations. Hip Int 2009; 19: 215-20.

6. Tóth K, Mécs L, Kellermann P. Early experience with the Depuy Proxima short stem in total hip arthroplasty. Acta Orthop Belg 2010; 76: 613-8.

7. Carulli C, Felici I, Martini C, Civinini R, Linari S, Castaman G, Innocenti M. Total hip arthroplasty in haemophilic patients with modern cementless implants. J Arthroplasty 2015 ; 30: 1757-60.

8. Wesley C, Hany B. Assessment tools: harris hip score. In: The Hip: Preservation, Replacement, and Revision. Cashman J, Goyal N, Parvizi J (eds.) Brooklandville, MD: DTPC, 2015.

9. Diaz-Ledezma C, Hussam A, Muheidat F, Wood A. Assessment tools: health-related quality of life measurements and other hip-specific scores in hip surgery. In: The Hip: Preservation, Replacement, and Revision. Cashman J, Goyal N, Parvizi J (eds.). Brooklandville, MD: DTPC, 2015.

10. Hawker GA, Mian S, Kendzerska T, French M. Measures of adult pain: Visual Analog Scale for Pain (VAS Pain), Numeric Rating Scale for Pain (NRS Pain), McGill Pain Questionnaire (MPQ), Short-Form McGill Pain Questionnaire (SF-MPQ), Chronic Pain Grade Scale (CPGS), Short Form-36 Bodily Pain Scale (SF-36 BPS), and Measure of Intermittent and Constant Osteoarthritis Pain (ICOAP). Arthritis Care Res (Hoboken) 2011; 63 Suppl. 11: S240-52.

11. Morrey BF. A historical perspective of hip arthroplasty and reconstructive surgery. In: The Hip: Preservation, Replacement, and Revision. Cashman J, Goyal N, Parvizi J (eds.) Brooklandville, MD: DTPC, 2015.

12. Gomez PF, Morcuende JA. A historical and economic perspective on Sir John Charnley, Chas F. Thackray Limited, and the early arthoplasty industry. Iowa Orthop J 2005; 25: $30-7$.
13. Canale ST, Beaty J. Campbell's Operative Ortophaedics. Hardbound 2007; 23.

14. Kim YH, Park JW, Kim JS. Is diaphyseal stem fixation necessary for primary total hip arthroplasty in patients with osteoporotic bone (Class C Bone). J Arthr 2013; 28: 13946.e1.

\section{Address for correspondence:}

\section{Andrzej Kotela}

Department of Orthopaedics and Traumatology of Musculoskeletal System

$1^{\text {st }}$ Faculty of Medicine

Medical University of Warsaw

ul. Wołoska 137, 02-507 Warsaw, Poland

Phone: +48 661166440

E-mail: andrzejkotela@op.pl 